\title{
The Role of Computer Assisted Language Learning (CALL) For English Language Learning of Elementary and High Schools In Indonesia
}

\author{
Miftachudin \\ Master Student of the University of Manchester \\ Oxford Road, Manchester, M13 9PL, UK \\ miftac4@ymail.com
}

\begin{abstract}
Computer Assisted Language Learning (CALL) or in another word collaborating computer with the classroom component to enhance language learning has a long history of pedagogical development since 1950 until nowadays which started with the simple program into microcomputers. It covers all learning processes using computers which advance the language skills of the learners. In the language courses, CALL is implemented by using several applications but this essay will solely mention 8 applications out of many. The study cases prove that those implementations offer several great values toward academic life. However, in order to achieve successful implementation, the preconditions or requirements of the CALL implementation must be fulfilled. In Indonesia, the advent of some hindrances such as cost, teacher trainings are the main issues to fulfil those requirements. Alternatively, several recommendations are proposed to refute the problems such as schools and local government cooperation, customisation learning technology and peer school teaching.
\end{abstract}

Keywords: CALL, Language Learning, Elementary and High Schools 


\section{Abstrak}

Komputer sebagai Media Pembelajaran Bahasa ( CALL) atau dengan kata lain komputer yang berkolaborasi dengan komponen kelas untuk meningkatkan pembelajaran bahasa memiliki sejarah panjang pengembangan pedagogis sejak tahun 1950 sampai saat ini, yang dimulai dengan program sederhana hingga mikrokomputer . Hal Ini mencakup semua proses pembelajaran menggunakan komputer yang dapat memajukan kemampuan bahasa peserta didik .Dalam pengajaran bahasa, CALL diimplementasikan dengan menggunakan beberapa aplikasi, tetapi esai ini hanya akan menyebutkan 8 aplikasi diantara banyak aplikasi yang ada. Studi kasus membuktikan bahwa implementasi aplikasiaplikasi tersebut menawarkan beberapa kontribusi yang besar terhadap kehidupan akademik . Namun, untuk mencapai keberhasilan itu , pra kondisi atau persyaratan dalam pelaksanaan CALL harus dipenuhi . Di Indonesia , munculnya beberapa kendala seperti biaya , pelatihan guru adalah isu utama guna memenuhi kebutuhan tersebut. Sebagai alternatif, beberapa rekomendasi diusulkan untuk mengatasi masalah tersebut, seperti kerjasama antara sekolah dan pemerintah daerah, kustomisasi teknologi pembelajaran, dan pengajaran sebaya.

Kata Kunci: CALL, Pembelajaran Bahasa, Sekolah Dasar dan Menengah Atas

\section{Introduction}

Computers are highly in demand since their functions are not only to calculate numerals but also to assist human activities. In the case of language learning, computers have significant contributions and lead to better teaching (Hagen, 1993:21). Furthermore, since 1950s they tend to be more popular for language learning because there is a need to figure out the efficient and scientific methods in language teaching (Beatty:2003). Computers are prominent devices among other technologies which should attach to collaborate with the curriculum requirement and reach certain learning goals. In addition, pre-condition 
such as technology-literate teachers is needed to guarantee the successful implementation (Hagen:1993).

In Indonesia, English is mainly used as a second language which is learned formally at school. It is taught by using text books and the students need to follow the language instruction within. In fact, the classroom sometimes tends to be boring because students face the same learning method every day. As a result, they lack motivation in learning. Simultaneously, that condition affects the academic life and learning process.

The aim of this essay is to give an overview of CALL and evaluate its potential use for language learning. Firstly, a literature review providing background to CALL will be given. Secondly, opportunities of CALL for language learning will be presented. Thirdly, the potential implementation of CALL in English language learning of elementary and senior high education in Indonesia will be analysed. Next, recommendations of using CALL in English language learning of elementary and high schools in Indonesia will be proposed. Finally, a conclusion will be drawn.

\section{Discussion}

\section{The description of CALL}

Beatty (2003) defined CALL as the process of using computers in learning which results learner's language improvement. By using this terminology, appropriate materials and methodologies are easily recognized by learners, teachers and researchers. Furthermore, they can be adapted to various teaching and learning styles. CALL covers the issues of material design, technology, theories of pedagogical and 
instruction modes. Since the nature of computers has changed, CALL persistently develops pedagogy terms and technology advances in both hardware and software. CALL can be implemented in and out of the class. It can be used in the classroom as an honour for good learners or a reinforcement tool for students who work at a slower pace. Conversely, out of the classroom, it is a complete language learning application which serves individual away from his or her resident. CALL is mostly concerned with autonomous learning where learners may have chances to study independently from the teachers and organise their personal learning. Regarding the design of CALL materials, endless revisiting is granted that helps learners practice and have remedial for certain parts they need.

\section{CALL in the 1950s and 1960s}

In 1959, The University of Illinois collaborating with a business partner, Control Data Corporation developed Program Logic/Learning for Automated Teaching Operation (PLATO) system in which the first and most significant application for teaching and learning of language at the computer was used. This system had the capability to give feedback such as an examination collaborated with remedial work based on learners' incorrect answers. The learners need to follow the same steps in the same fashion with point rewards and advancement for correct answers. The exercises were mainly conversion of traditional textbook exercises and avoided the usage of computer features (Beatty:2003).

On the other hand, the invention of simulation brought the special nature of computer to allow for branching of choices. It can be seen from the machine interface that under the constructivist model instruction 
where the learners' knowledge about the world rationalised the task. The classroom altered into computer based environment where the learner may make frequent errors in a non-threatening way. As a result of simulation in independent learning situations which allow for repeated attempts, the positive stress which often fuels learning may reduce (Beatty, 2003).

\section{CALL in the 1970s and 1980s}

In this period, the classification of computers was divided into three categories: mainframe computers, mini-computers and microcomputers. The former category was room-sized machines. The second one was similar to what it is recently called as a server. The latter category is what we call desktop computers or personal computer such as portables and laptops (Beatty: 2003).

CALL research in this period focused on videodisc technology, a high-volume storage system. Its technology allowed less powerful computers which commonly relied on textual exercise to go beyond the behaviourist models of instruction (Beatty:2003).

According to Bush and Crotty (1991), promoting listening rather than speaking, using the target language exclusively, implicit over explicit grammar, and correcting or providing evidence through modelling and certain effort to make a low-anxiety atmosphere were pointed out as some videodisc learning features.

\section{CALL in the 1990s}

The multimedia CALL environment is the ones cited so far provide an overview of the types of features likely to be offered among thousands of new publicity of CALL (Beatty:2003). In accordance with 
Murray, Morgenstern and Furstenberg (1991:97-118), the guidelines concern with how to evaluate narrative-driven multimedia learning environments such as multiplicity of protagonist, multiplicity of plot events, knowledge-based choice points, choice-points based on temperament of the learner, whimsical surprises, multimedia for presentation and intrinsic rather than extrinsic rewards. Those points are useful to decide the possibility and desire in multimedia context among many non-narrative materials that do not accommodate the guidelines.

\section{Applications of CALL}

Eight CALL applications are available including word processing, games, literature, corpus linguistic, computer mediated communication (CMC), WWW resources, adapting other materials for CALL and Personal Digital Assistant (PDA) (Beatty, 2003:52).

Sharma and Barret (2007:69) mention office software in general as CALL applications including word processors, data base processors, spread sheets applications, and program of presentations. In fact, they only mention the two of them; word processors and presentation programs which can be collaborated to language learning.

In the term of Blended Learning, Sharma and Barret (2007) combine proper technology with direct teaching features. However, most of their applications in language courses use computers, some hardware and software within to enhance the learning process. Search engines, word processors, media players, CD Roms, internet, Interactive White Boards (IWB), emails, internet chat rooms, Virtual Learning Environments (VLE), blogs and wikis are the sample of technology used in the practice of Sharma and Barret. 


\section{Requirements to implement CALL in the classroom}

Hagen (1993) concluded that the successful implementation of new technology into the language classroom requires special precondition: support of senior management, a whole-school approach, technology-literate teachers, technician support, a designated language learning accommodation (for example sound proofing) and a budget for staff training, materials development and the purchase of good-quality course material.

Sharma \& Barret (2007) also listed some factors that affect the technology usage in language learning. The factors cover the attitude of teachers and learners to technology, learners' level affecting the appropriate use of technology, teacher training related to novelty of the technology, teachers and learners availability to access technology, and the cost factor to provide new technology.

\section{Values of the CALL implementations for language learning}

Sharma and Barret (2007) stated that computers as one of the technology devices in Blended Learning collaborated with a face-to-face (F2F) classroom component offer several important opportunities.

First, learning with technology is motivating to some extent. For example playing language game such as hang-man, it gives learners joy and knowledge consecutively. Also, there is a direct evaluation after learning interaction that learners may proceed to the next level or repeat a certain part as much as they want to. 
Second, flexibility in venue, timetable, and in terms of level are great values in using technology. Video conference meet people's need in

communication from different time and place without any direct interaction. Virtual Learning Environment (VLE) helps learners who lack of ability in note taking. Therefore, they can grasp the material at later date from online teachers' note. In terms of level, technology such as CD Rom is created to promote certain level band such as beginner, intermediate, and advanced. Intermediate students are allowed to learn beginner material in order to review and trace back what they have learnt. Alternatively, they may try to start the advanced level in purpose of testing themselves.

Third, web-based tasks tend to be more interactive than paper based tasks because it lets learners make choices. In the case of mixmatch collocation task, learners may try to match one word to the others and start to make a new phrase.

Next, technology also leads to independent learning. Learners are able to access learning materials from everywhere (home, office, or even café), review any materials they have not understood and get evaluation instantly. Invitingly, they may manage the learning timetable based on their own preference since the material is available online.

Lastly, updated online materials in the internet are more available than the printed one. There is a wide range of material in the internet. Thus teachers should choose the most current, appropriate and reliable to the topic of learning. By using updated online materials, teachers save a lot of time in preparing materials because one material can be used 
thousands of time to different groups and there is no time consuming in duplicating the worksheet like in the paper based materials.

\section{English Language learning for elementary and high school in Indonesia}

Education curriculum in Indonesia

The curriculum of education in Indonesia has an autonomous system which is regulated by local government as it is explicated in the act of Indonesian Republic no. 20 year 2003 about the National Educational System. Specifically, it is defined in the chapter 4, article 10 about rights and obligations of state and local government. They can direct, advice, assist and supervise educational administration as stated in the act (Bidang DIKBUD KBRI Tokyo 2003:5).

The implementation of this policy becomes the curriculum named Kurikulum Tingkat Satuan Pendidikan (Educational Unit base Curriculum). KTSP abbreviated from Kurikulum Tingkat Satuan Pendidikan is operational curriculum which are composed by and performed in each educational unit. It has an educational objective in a certain educational unit, structure and curriculum contents in a certain educational unit, an academic calendar and syllabus (Badan Standar Nasional Pendidikan 2006:3).

Each group or educational unit may develop appropriate and relevant KTSP under the supervision and coordination of Education Department or that of county / Regency Religious Affairs Department for elementary education and that of Province Religious Affairs Department for secondary education. The development itself must consider the standard of content and alumni competency. There are seven principles in 
developing KTSP and one of them is the awareness towards the development of science, technology and art. Thus, the spirit and content of the curriculum should promote learners to experience in updating and using science, technology and art (Badan Standar Nasional Pendidikan, 2006).

Current learning resources in English language learning of elementary and high school in Indonesia

Learning resources which are used in teaching learning process can be indicated in syllabus. Badan Standar Nasional Pendidikan (2006:5) defined that syllabus are lesson plans in a certain unit of topics or a learning-subject which cover standards of competencies, basic competences, main discussions, learning activities, achievement indicators in assessment, assessments, time allocations and learning resources.

Learning resources which have been observed on some syllabus indicates that the teachers have used some application of CALL. The findings are concluded as follow.

Pancaran (2009) mentioned some learning resources that he used in language teaching in senior high schools such as WWW, cassettes, CDs, English newspapers, English modules, tape scripts, overhead projectors (OHP) and LCDs. It means that one in a time, he tried to swap English modules or English newspapers which are paper based materials with other resources such as web based materials and other technologies. Surely, the web based resources must involve computers to access them.

Meanwhile, Pancaran (2009) used course books, cassettes or CD recordings, teaching aids and related images when he taught fifth grade 
elementary students. In addition Sugiono (2010) used pictures, conversation scripts and English modules to teach his 9 grade elementary students.

Drawbacks in implementing CALL in English language learning of elementary and high school in Indonesia

As a developing country, Indonesia faces many problems in managing its budget. In the field of education, government only allocated $15.81 \%$ for The National Education Ministry, Rp 51.8 trillion from $\mathrm{Rp}$ 327.6 trillion of the 2010 fiscal. In fact, this amount is not enough to improve the education quality because $25 \%$ of the budget has been allocated to teachers' salary and the other $25 \%$ of that is used to pay school operational cost (The Jakarta Post, 2009). Simultaneously, it creates another problem in administering education and complementing learning tools such as technology equipment. In the case of computer technology, it usually comes together with building a computer lab to accommodate language learning, computer peripherals, an internet connection, staff and teacher trainings and additional monthly expenses for maintenance (Noni, 2010:2). This bundle cost a great amount of money which cannot be afforded by the government.

In addition, teachers have different attitudes to respond the new technology whether it is a challenge or a burden. Based on writer's teaching experience in computer classes, teachers who are accustom with face-to-face learning find to be difficult to manage their time in learning how to use computer or new technology especially those who teach in elementary or high school. It may not simply difficulties but there can be other factors such as laziness, reluctant to be innovative, unlike 
challenge, quite busy with extra errands or other excuses. Thus, they cannot bear their mind to be technology literate and develop teaching creativity (Noni:2010).

Further, the archipelago country of Indonesia with 13.667 islands including 1000 inhabited ones still has a problem in distributing resources to improve the educational quality and output. For example, The Jakarta Post (2009) stated that in East Kalimantan of Indonesia well known as a rich region, the local government planned to allocate 4.000 laptops gradually for teachers in International Project Schools. Following that, there will be training for teachers to improve computer skill programs. There must be a good management to balance between the centre of development, country sides and remote areas. It is an important issue because the national standard of national exam is same although the facilities are on the other hand.

From the students' point of view, most of them are technologically savvy and computer such as playing games online, socializing online or surfing the internet using mobile-phone. However, those facts may liable to them into violence and irresponsible activities. (The Jakarta Post, 2009).

Recommendations of using CALL in English language learning for elementary and high schools in Indonesia.

Comparing the requirements and current condition of Indonesian education, it is hardly to believe that Indonesia is capable to use CALL in language classroom at the moment. On the other hand, there is a new hope because the government tend to initiate maintaining $20 \%$ budget for education from national fiscal (The Jakarta Post, 2009). 
Obviously, computers are the most prominent technology but technology itself covers wide range of devices. As long as they can collaborate with the classroom component, fulfil the curriculum, and promote the objectives of learning, teachers may combine and use the most appropriate technology they have.

Alternatively, the schools as a whole cooperate with the local government to make and find the way to make all requirements in using CALL. The autonomy system lets this to be applicable because state government deliberate local government using their own method to manage their area.

In the case of teacher training, peer school teaching is the way to speed up transferring computer skills. In Indonesia, International Project Schools have the highest rank among that of the other schools. Normally, they have ultimate services, great academia components, technology and facilities. The non-International Project School should have set at the same table with the International ones in order to teach and learn together about the use of CALL. Finally, the cycle process of transfer will direct to students and teach them how to use technology appropriately in field of education.

\section{Conclusion}

The CALL overview and the evaluation of potential use of computers have been delivered in details. In the first part, a literature review of CALL was given. Next, opportunities of CALL for language learning were also presented in brief. Moreover, the potential implementations of CALL in English language learning of elementary and senior high education in Indonesia was analysed. Finally, 
recommendations of using CALL in English language learning of elementary and high schools in Indonesia were proposed.

CALL covers all learning processes using computers which advance the language skills of the learners. They have a long history of pedagogical development since 1950 until nowadays which started with the simple program into microcomputers. Their implementations include many kinds of applications. However, there are only 8 types mentioned in this essay. Based on study cases, those implementations have some great values toward academic achievement but the requirements to collaborate CALL with any classroom components must be considered in order have a successful implementation.

In Indonesia, those requirements are likely doubtful to achieve because some problems persist such as budget or cost, teacher trainings etc. However, there are some recommendations were proposed to refute the condition in Indonesia such as schools and local government cooperation, customisation learning technology and peer school teaching.

\section{References}

Badan Standar Nasional Pendidikan. (2006). Panduan Penyusunan Kurikulum Tingkat Satuan Pendidikan Jenjang Pendidikan Dasar dan Menengah [online]. Available from: http://bsnpindonesia.org/id/wpcontent/uploads/kompetensi/Panduan_Umum_KTSP.pdf [Accessed August 21, 2011].

Beatty, K. (2003). Teaching and Researching Computer-Assisted Language Learning. London: Pearson Education Limited.

Bidang DIKBUD KBRI Tokyo. (2003). Undang-Undang Sistem Pendidikan Nasional [online]. Available from: 
http://www.inherent-dikti.net/files/sisdiknas.pdf

[Accessed August 14, 2011].

Bush, M.D. and Crotty, J. (1991). Interactive videodisc in language teaching. In Betty, K. Teaching and Researching ComputerAssisted Language Learning. London: Pearson Education Limited.

Hagen, S. ed. (1993). Using Technology in Language Learning. London: City Technology College Trust Limited.

Hill, Winfred F. (1985) Learning: A Survey of Psychological Interpretation. United States of America: Harper \& Row Publisher Inc.

Murray, J., Morgenstern, D., et al. (1991). The Athena Language Learning Project: design issues for the next generation of computer based language-learning tools. In Beatty, K. Teaching and Researching Computer-Assisted Language Learning. London: Pearson Education Limited.

Noni, N. (2010). Penerapan Teknologi Informasi dan Komunikasi (TIK) dalam Pendidikan [online]. Available from: http://blog.unm.ac.id/nurdinnoni/files/2010/04/Modul-1.pdf [Accessed: August 31, 2011].

Pancaran, Y. (2009). Silabus Bahasa Inggris [online]. Available from: http://www.docstoc.com/docs/75761370/silabus-bahasa-inggris [Accessed August 21, 2011].

- Silabus Bahasa Inggris Kelas 5 SD [online]. Available from: http://www.docstoc.com/docs/8616952/SilabusBahasa-Inggris-SD-Kls-5 [Accessed August 21, 2011].

Sharma, P. and Barret, B. (2007). Blended Learning: Using technology in and beyond the language classroom. Oxford: Macmillan Education.

Sugiono, U. (2010). Silabus bahasa inggris kelas 9 smp [online]. Available from: http://www.docstoc.com/docs/23120351/silabus-bahasa-inggriskelas-9-smp [Accessed August 21, 2011].

The Jakarta Post. (2009). Education, defense budgets 'inadequate'. The Jakarta Post [online]. Available from: http://www.thejakartapost.com/news/2009/08/04/educationdefense-budgets-'inadequate'.html [Accessed: August 31, 2011].

The Jakarta Post. (2009). Education ministry told to improve budget spending [online]. Available from: 
http://www.thejakartapost.com/news/2009/10/28/educationministry-told-improve-budget-spending.html [ Accessed: August 31, 2011].

The Jakarta Post. (2009). Responding to the 'digital age' in education [online]. Available form: http://www.thejakartapost.com/news/2009/08/27/respondingdigital-age039-education.html [Accessed: August 31, 2011].

The Jakarta Post. (2009). Rp 6.3b allotted for laptops for teachers. The Jakarta Post [online]. Available from: http://www.thejakartapost.com/news/2009/08/01/rp-63ballotted-laptops-teachers.html [Accessed: August 31, 2011]. 